\title{
Concurrent müllerianosis of the urinary bladder and the umbilicus presenting with umbilical bleeding: a rare case report and review of the literature
}

\author{
Syu Jhang ${ }^{1,2,3}$, Marcelo Chen ${ }^{1,2,3}$ and Li-Chen Chen ${ }^{1,2,3^{*}}$
}

\begin{abstract}
Background: Müllerianosis is a very rare neoplasm composed of two or three Müllerian derived tissues (endosalpinx, endometrium and endocervix). We report the first case of concurrent müllerianosis of the urinary bladder and the umbilicus presenting with umbilical bleeding.

Case presentation: A 43-year-old Asian premesopausal female, gravida 1, para 1, presented with intermittent umbilical bleeding. An umbilical nodule and a bladder tumor on the posterior wall of the urinary bladder were identified. She underwent transurethral resection of the bladder tumor and excision of the umbilical nodule successively. Diagnosis of müllerianosis was confirmed by the histological and immunological features. No tumor recurrence was noted at 6 months of follow-up.

Conclusions: Müllerianosis is extremely rare and mainly reported in the urinary bladder, and generally affects women of reproductive age. Despite the common presentations of müllerianosis of the urinary bladder including irritative voiding symptoms, abdominal/pelvic pain and gross hematuria, our rare case had no symptom except umbilical bleeding. The possibility of concurrent bladder müllerianosis should be considered when müllerianosis is found at other location. We suggest a surgical intervention to establish the correct pathological diagnosis because it is essential to exclude malignant neoplasms of the urinary bladder. The majority of patients have a favorable prognosis.
\end{abstract}

Keywords: Müllerianosis, Umbilicus, Urinary bladder

\section{Background}

Müllerianosis is a very rare neoplasm composed of at least two of müllerian-derived tissues, namely endosalpinx, endometrium and endocervix, [1] and has mainly been reported in the urinary bladder. Only approximately 20 cases of müllerianosis of the urinary bladder have been documented in the English literature [2].

\footnotetext{
* Correspondence: cetaceachen@gmail.com

'Department of Urology, Mackay Memorial Hospital, No. 92, Sec. 2 ,

Zhongshan N. Rd, Taipei 10449, Taiwan

${ }^{2}$ School of Medicine, Mackay Medical College, Sanzhi, Taiwan

Full list of author information is available at the end of the article
}

Herein, we report the first case of concurrent müllerianosis of the urinary bladder and the umbilicus presenting with umbilical bleeding.

\section{Case presentation}

A 43-year-old Asian premesopausal female without known underlying disease or history of surgery, gravida 1 , para 1, complained of intermittent umbilical bleeding for several weeks. She had a normal body mass index (24.1 $\left.\mathrm{kg} / \mathrm{m}^{2}\right)$. She had no other symptoms including abdominal/ pelvic pain, gross hematuria, urinary frequency,

(c) The Author(s). 2020 Open Access This article is licensed under a Creative Commons Attribution 4.0 International License which permits use, sharing, adaptation, distribution and reproduction in any medium or format, as long as you give appropriate credit to the original author(s) and the source, provide a link to the Creative Commons licence, and indicate if changes were made. The images or other third party material in this article are included in the article's Creative Commons licence, unless indicated otherwise in a credit line to the material. If material is not included in the article's Creative Commons licence and your intended use is not permitted by statutory regulation or exceeds the permitted use, you will need to obtain permission directly from the copyright holder. To view a copy of this licence, visit http://creativecommons.org/licenses/by/4.0/ The Creative Commons Public Domain Dedication waiver (http//creativecommons.org/publicdomain/zero/1.0/) applies to the data made available in this article, unless otherwise stated in a credit line to the data. 
micturition pain, dysmenorrhea or dyspareunia. On pelvic examination, she had no lifting tenderness. She visited our Obstetrics and Gynecology clinic, where a bladder lesion was incidentally identified on transabdominal ultrasound. A firm, irregular and unmovable nodule was also noted in the umbilicus with a diameter of $2 \mathrm{~cm}$ (Fig. 1). She had no lifting pain Urinalysis showed 6 red blood cells per highpower field. Abdominal computed tomography revealed a protruding mass $2.4 \mathrm{~cm}$ in diameter located on the posterior wall of the urinary bladder (Fig. 2a) and another separate mass in the umbilicus (Fig. 2b) without communication between these two lesions. She first underwent transurethral resection of the bladder tumor (TURBT) (Fig. 3), and a microscopic histological examination revealed multiple foci of glands with dilated lumen and surrounding short spindle cells. The glands were composed of bland-looking cells with a tall columnar shape (Fig. 4a). Immunohistochemically, estrogen receptor (ER) and CD10 were expressed in the surrounding short spindle cells (Fig. 5a and b). Cilia and ER expressions were also noted in dilated glands without spindle cell cuffing (Fig. $4 \mathrm{~b})$. These histological findings were consistent with endometrium and endosalpinx, and a diagnosis of müllerianosis was made. Occult malignancy was not seen. She had no discomfort after the surgery except for intermittent umbilical bleeding. Thus, excision of the umbilical tumor was performed. The pathological finding was also compatible with müllerianosis. Physical examination and cystoscopy at 6 months of follow-up revealed no tumor recurrence.

\section{Discussion and conclusions}

Young and Clement [3] reported the first case of müllerianosis in the urinary bladder in 1996 and defined this

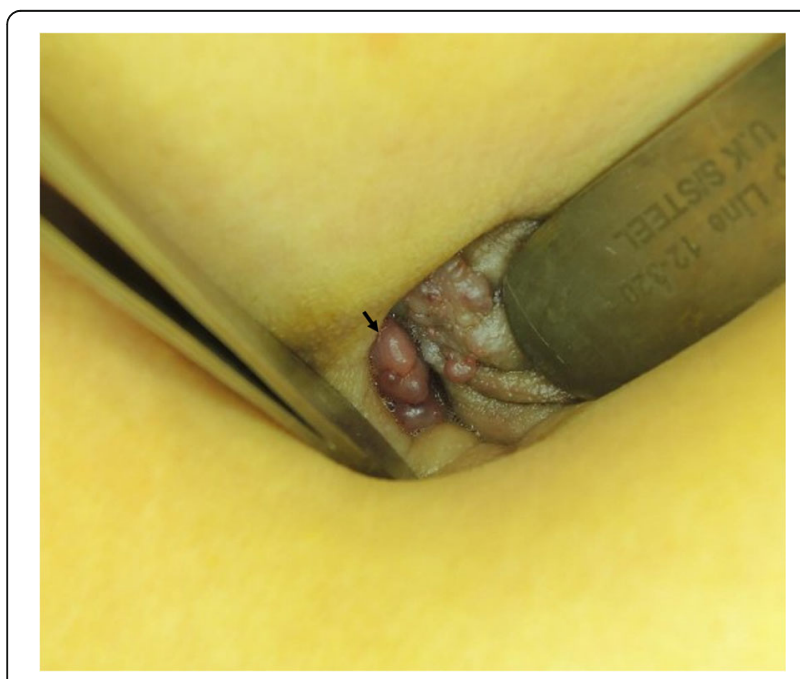

Fig. $1 \mathrm{~A}$ firm, irregular and unmovable umbilical mass with intermittent bleeding (arrow) disease as "a lesion seen at any site containing admixtures of endosalpingiosis, endometriosis, and endocervicosis." Twenty-one cases occurring in the urinary bladder have been documented in 19 articles (Table 1) in the English literature, accounting for the majority of cases of müllerianosis [18]. Some sporadic cases have been reported in the ureter, spinal cord, inguinal lymph nodes and mesosalpinx [2]. To the best of our knowledge, this is the first report to describe müllerianosis of the umbilicus. Due to its rarity, the prevalence of müllerianosis is unknown.

Several hypotheses of the pathogenesis of müllerianosis of the urinary bladder have been proposed; however, the mechanism is not clearly understood. Implantation, one of the most discussed theories, suggests that müllerian tissue implants into the urinary bladder wall during pelvic surgery [3]. However, this cannot explain why müllerianosis is found in surgery-naïve patients or in organs other than the urinary bladder. Ten of the 19 cases (52.6\%) with detailed surgical records, the present case included, had not experienced any pelvic surgery such as hysterectomy or cesarean delivery. Another theory, metaplasia, advanced by Donne et al., [4] is based on the presence of two or more müllerian-derived tissues, which implies the potential of müllerian epithelium to differentiate rather than the implantation of a single type of the tissue. Moreover, of the 20 cases with marked tumor locations, a total of 16 tumors (80\%) were situated on the posterior wall or the dome of the urinary bladder, a place adjacent to the peritoneum and more sensitive to female hormones. Koren et al. [9] in 2006 reported a case supporting the metaplasia theory with the metaplastic epithelium in continuity with the urothelium. The present case is also supportive of metaplasia because of concurrent occurrence of the bladder and the umbilical masses.

Müllerianosis of the urinary bladder mainly affects women of the reproductive age, with a mean age at diagnosis of 44.6 years (range 27 to 70 years). Of the total 22 patients with müllerianosis of the urinary bladder, five were postmenopausal females. The most common symptoms have been reported to be irritative voiding symptoms (54.5\%) including frequency, urgency, urge incontinence and dysuria, abdominal/pelvic pain $(45.5 \%)$ and gross hematuria (36.4\%). These symptoms occurred cyclically in six cases $(27.3 \%)$, mostly during the menstrual period. One patient with a tumor on the ureterovesical junction presented with renal colic [13]. Our case had none of the symptoms associated with bladder lesions, and only had umbilical bleeding.

Grossly, müllerianosis of the urinary bladder has been described as "sessile polypoid", [17] "submucosal", [6] or "smooth with normal appearing overlying mucosa" [14] on cystoscopic examinations. The gross appearance of the 

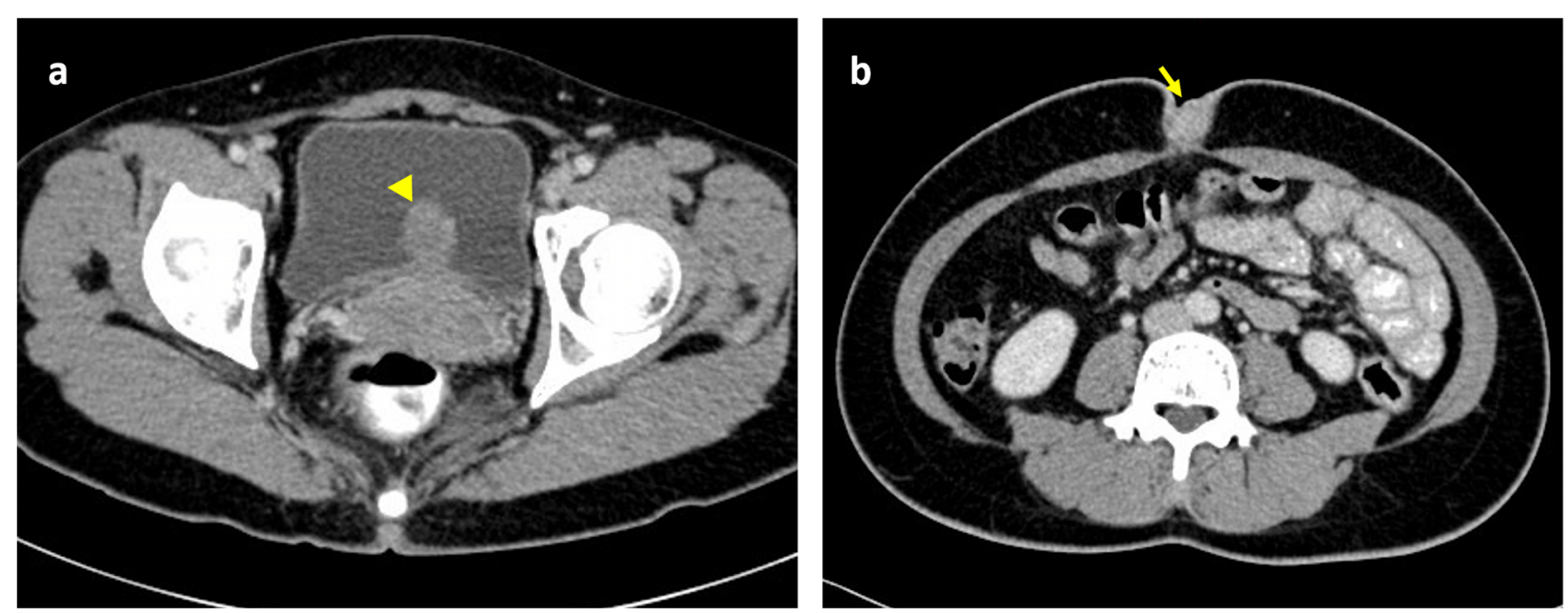

Fig. 2 Computed tomography revealing a. A protruding mass on the posterior wall of the urinary bladder (arrowhead). b. A mass in the umbilicus (arrow)

bladder tumor in our case revealed the similar findings as a mass with hemorrhage underneath the intact epithelium. Histologically, it revealed multiple foci of glands with variable size lined by tubal, endocervical, or endometrial epithelium situated in the lamina propria and muscularis propria $[2,15]$. These glandular cells were immunohistochemically positive for ER and progesterone receptor (PR) [9]. In addition, the stroma surrounding the endometrial glands diffusely expressed CD10, and the epithelia showed positive staining for Ca-125 [15].

Both medical and surgical treatments can be used for müllerianosis of the urinary bladder. Regardless of the

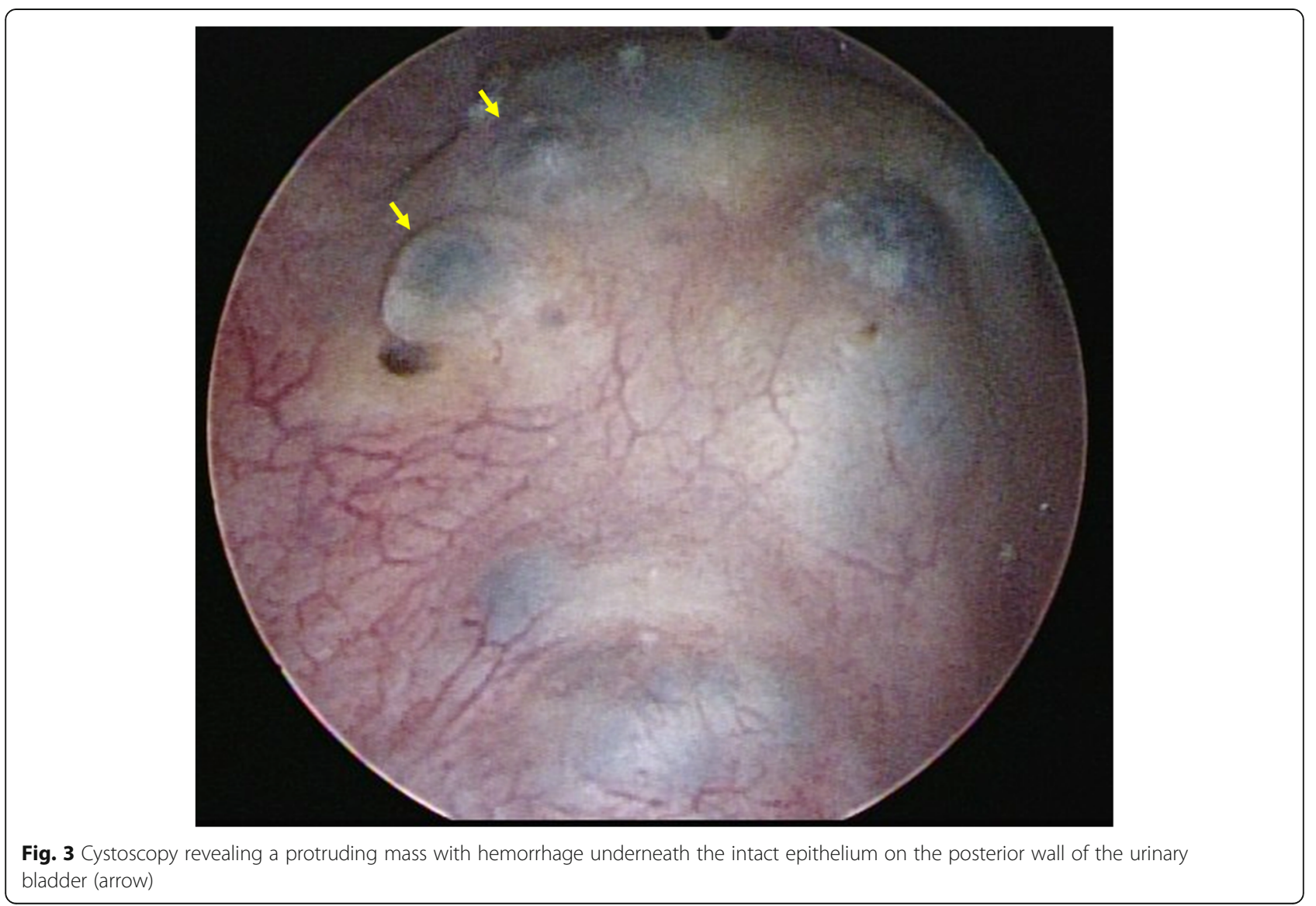




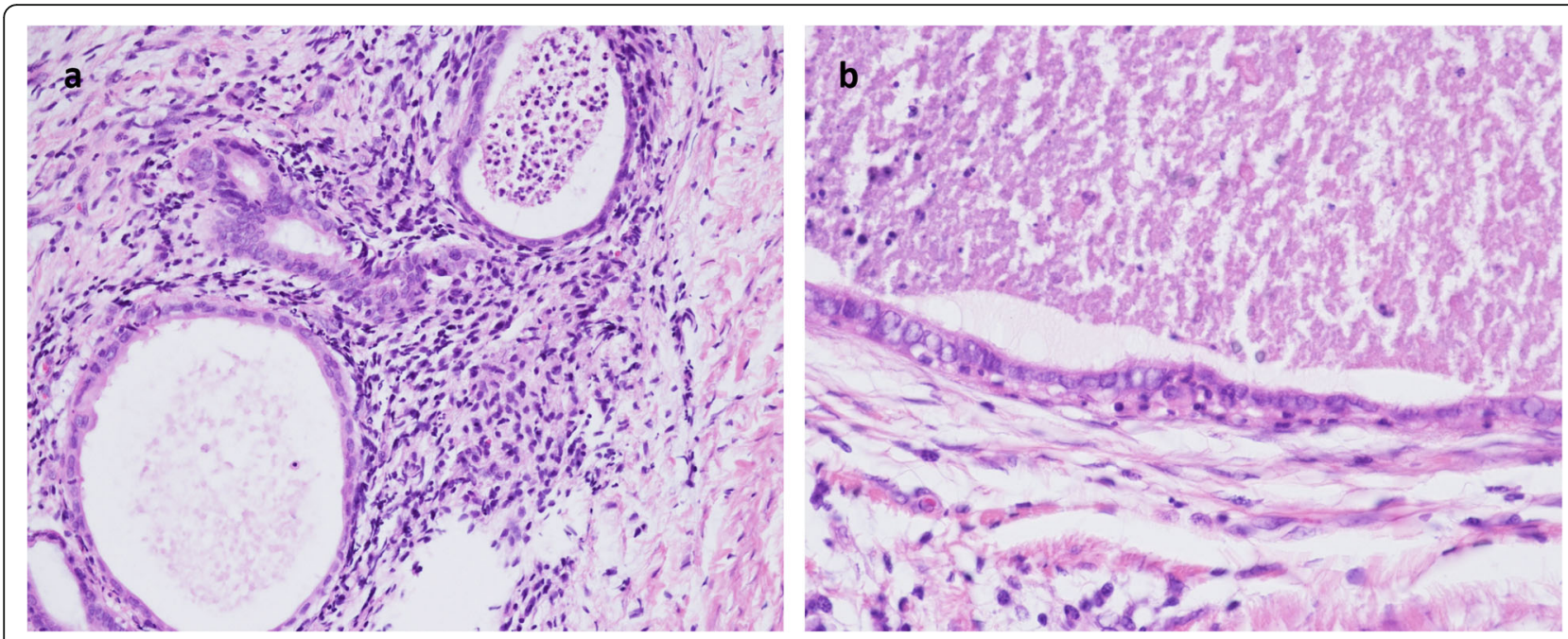

Fig. 4 Microscopic histological examination revealing a. Glands with dilated lumen and surrounding short spindle cells consistent with endometriosis. $\mathbf{b}$. Glands with no spindle cell but cilia consistent with endosalpinx

lack of consensus on the choice of therapy, most physicians and patients chose the surgical intervention in the reported cases, and most of the patients had a favorable prognosis. Sixteen patients underwent TURBT, only five of whom required subsequent medical treatment, [12, 13] or partial cystectomy [16, 18, 19] due to persistent symptoms or tumor recurrence. None of the four patients who underwent partial cystectomy had recurrence; by contrast, in two cases using gonadotropin-releasing hormone (GnRH) analogues to inhibit pituitary and gonadal function to reduce the tumor volume as medical treatment, cystoscopy showed smaller but persistent tumors at 3 months and 2 years of follow up. There was no documented distant metastasis or mortality in the cases with short-term follow-up (1-24 months).
Müllerianosis of the urinary bladder mimics several bladder neoplasms such as cystitis glandularis and nephrogenic adenoma [9]. It is most important to differentiate between müllerianosis and invasive adenocarcinoma, both of which exist in the lamina propria and muscularis propria. A case of bladder endometrioid adenocarcinoma complicating müllerianosis has been reported [8].

In conclusion, müllerianosis is a rare neoplasm which mainly affects women of reproductive age. The common presentations of müllerianosis of the urinary bladder include irritative voiding symptoms, abdominal/pelvic pain and gross hematuria. In our case, multifocal müllerianosis were separately located on the urinary bladder and the umbilicus, which implies that the possibility of
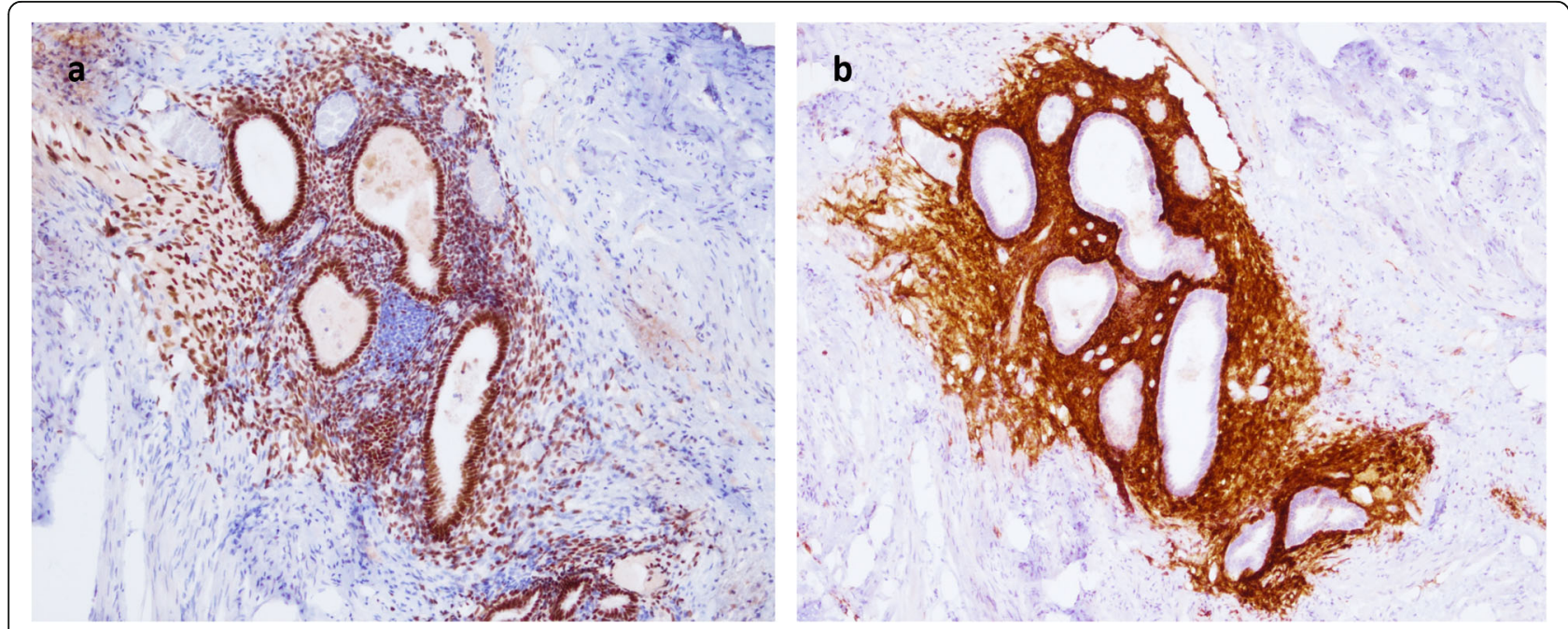

Fig. 5 Positive stains for a. Estrogen receptor. and b. CD10 
Table 1 Review of reported cases of müllerianosis of the urinary bladder

\begin{tabular}{|c|c|c|c|c|c|c|c|}
\hline $\begin{array}{l}\text { Case } \\
\text { Number }\end{array}$ & Age & Symptoms & $\begin{array}{l}\text { Operation } \\
\text { history }\end{array}$ & Tumor location & Treatment & Follow up & Reference \\
\hline 1 & 37 & N/A & \multirow{3}{*}{$\begin{array}{l}\mathrm{C} / \mathrm{S} \text { (one of } \\
\text { these three) }\end{array}$} & $P$ & TURBT & N/A & [3] \\
\hline 2 & 44 & Lower abdominal pain & & $P$ & TURBT & N/A & {$[3]$} \\
\hline 3 & 46 & Irregular menstruation & & $P$ & TURBT & N/A & [3] \\
\hline \multirow[t]{2}{*}{4} & 27 & Dysmenorrhea & None & $P$ & N/A & N/A & [4] \\
\hline & & $\begin{array}{l}\text { Irritative voiding symptom }{ }^{a} \\
\text { (dysuria) }\end{array}$ & & & & & \\
\hline \multirow[t]{2}{*}{5} & 38 & Pelvic pain & Hysterectomy & N/A & PC & N/A & {$[5]$} \\
\hline & & $\begin{array}{l}\text { Irritative voiding symptom } \\
\text { (dysuria) }\end{array}$ & & & & & \\
\hline \multirow[t]{4}{*}{6} & 48 & Lower abdominal pain & Hysterectomy & N/A & Biopsy & Persistent but significantly improved & [6] \\
\hline & & Dyspareunia & & & & & \\
\hline & & $\begin{array}{l}\text { Irritative voiding symptom } \\
\text { (frequency/urgency) }\end{array}$ & & & & & \\
\hline & & Hematuria & & & & & \\
\hline \multirow[t]{2}{*}{7} & 37 & Vaginal discharge & $\mathrm{C} / \mathrm{S}$ & $P$ & TURBT & N/A & [7] \\
\hline & & Iliac fossa pain & SO & & & & \\
\hline \multirow[t]{2}{*}{8} & $53^{b}$ & $\begin{array}{l}\text { Irritative voiding symptom } \\
\text { (dysuria) }\end{array}$ & N/A & $P$ & TURBT & N/A & [8] \\
\hline & & Hematuria & & & & & \\
\hline \multirow[t]{3}{*}{9} & 41 & $\begin{array}{l}\text { Irritative voiding symptom } \\
\text { (dysuria) }\end{array}$ & None & $P$ & TURBT & N/A & [9] \\
\hline & & Pelvic pain & & & & & \\
\hline & & Hematuria $^{a}$ & & & & & \\
\hline \multirow[t]{2}{*}{10} & $70^{\mathrm{b}}$ & Vaginal bleeding & Hysterectomy & Trigone & N/A & N/A & [10] \\
\hline & & & SO & & & & \\
\hline \multirow[t]{4}{*}{11} & 45 & Pelvic pain & $\mathrm{C} / \mathrm{S}$ & $P$ & Biopsy and PC & Complete symptoms relief & [11] \\
\hline & & Dysmenorrhea & & & & & \\
\hline & & Irritative voiding symptom & & & & & \\
\hline & & Hematuria $^{a}$ & & & & & \\
\hline 12 & 32 & $\begin{array}{l}\text { Irritative voiding symptom }{ }^{a} \\
\text { (dysuria) }\end{array}$ & N/A & $\begin{array}{l}\text { Right lateral } \\
\text { wall }\end{array}$ & $\begin{array}{l}\text { TURBT and } \\
\text { GnRH analogue }\end{array}$ & $\begin{array}{l}\text { Persistent but smaller tumor at } 2 \\
\text { years }\end{array}$ & [12] \\
\hline 13 & 28 & Hematuria & None & $\begin{array}{l}\text { Dome and left } \\
\text { lateral wall }\end{array}$ & TURBT & No tumor recurrence at 6 months & [1] \\
\hline \multirow[t]{3}{*}{14} & 50 & Renal colic & Hysterectomy & Left UVJ & TURBT and & Partial symptoms relief and smaller & [13] \\
\hline & & Dysmenorrhea & & & GnRH analogue & tumor at 3 months & \\
\hline & & Pelvic pain. & & & & & \\
\hline 15 & $61^{b}$ & $\begin{array}{l}\text { Irritative voiding symptom } \\
\text { (dysuria/frequency) }\end{array}$ & $\mathrm{C} / \mathrm{S}$ & $P$ & TURBT & N/A & [14] \\
\hline \multirow[t]{2}{*}{16} & 50 & Hematuria & None & $P$ & TURBT & N/A & [15] \\
\hline & & $\begin{array}{l}\text { Irritative voiding symptom } \\
\text { (dysuria) }\end{array}$ & & & & & \\
\hline 17 & 30 & Iliac fossa pain & None & $P$ & TURBT and PC & No tumor recurrence at 1 month & {$[16]$} \\
\hline 18 & 39 & $\begin{array}{l}\text { Irritative voiding symptom }{ }^{a} \\
\text { (dysuria) }\end{array}$ & None & $P$ & TURBT & N/A & [17] \\
\hline \multirow[t]{3}{*}{19} & $64^{\mathrm{b}}$ & Lower abdominal pain & $\mathrm{C} / \mathrm{S}$ & Left UVJ & TURBT and PC & Complete symptoms relief & [18] \\
\hline & & Repeat UTI & Hysterectomy & & & & \\
\hline & & Hematuria & Appendectomy & & & & \\
\hline
\end{tabular}


Table 1 Review of reported cases of müllerianosis of the urinary bladder (Continued)

\begin{tabular}{|c|c|c|c|c|c|c|c|}
\hline $\begin{array}{l}\text { Case } \\
\text { Number }\end{array}$ & Age & Symptoms & $\begin{array}{l}\text { Operation } \\
\text { history }\end{array}$ & Tumor location & Treatment & Follow up & Reference \\
\hline \multirow[t]{4}{*}{20} & $59^{b}$ & Repeat UTI & None & Dome & TURBT twice & Tumor recurrence and need PC & [19] \\
\hline & & Suprapubic pain & & & & & \\
\hline & & Hematuria & & & & & \\
\hline & & $\begin{array}{l}\text { Irritative voding symptom } \\
\text { (dysuria/incontinence) }\end{array}$ & & & & & \\
\hline 21 & 40 & $\begin{array}{l}\text { Irritative voiding symptom } \\
\text { (urgency/incontinence) }\end{array}$ & N/A & P & Biopsy & N/A & [2] \\
\hline 22 & 43 & Umbilical bleeding & None & $P$ & TURBT & No tumor recurrence at 6 months & $\begin{array}{l}\text { Present } \\
\text { case }\end{array}$ \\
\hline
\end{tabular}

N/A not available; C/S Cesarean section; $P$ posterior wall; TURBT transurethral resection of the bladder tumor; ${ }^{\text {a }}$ symptoms occur cyclically or during the menstrual period; $P C$ partial cystectomy; SO salopingo-oophorectomy; ${ }^{b}=$ postmenopausal patient; GnRH Gonadotropin-releasing hormone; UVJ ureterovesical junction; UTI urinary tract infection

concurrent bladder müllerianosis should be considered when müllerianosis is found at other location. Despite a favorable prognosis in the majority of patients, in view of the importance of establishing the correct pathological diagnosis, we suggest treatment with a surgical intervention consisting of TURBT and partial nephrectomy if recurrence occurs with persistent symptoms.

\section{Abbreviations}

ER: Estrogen receptor; PR: Progesterone receptor; TURBT: Transurethral resection of the bladder tumor; $\mathrm{GnRH}$ : Gonadotropin-releasing hormone

\section{Acknowledgments}

The authors would like to thank all colleagues who contributed to this study. We appreciate the assistance in pathological interpretation of department of pathology of Mackay Memorial Hospital assistance.

\section{Authors' contributions}

SJ and LCC conceived of the presented idea. SJ processed the experimenta data, performed the analysis and drafted the manuscript. MC revised the manuscript. All authors discussed the results and contributed to the final manuscript.

\section{Funding}

The authors received no financial support for the research, authorship, or publication of this article.

\section{Availability of data and materials}

The data used and analyzed during the current study are available from the corresponding author on reasonable request.

\section{Ethics approval and consent to participate}

We state that all human subjects provided written informed consent with guarantees of confidentiality. The ethics approval is not applicable.

\section{Consent for publication}

We state that the patient has given her written informed consent for publication.

\section{Competing interests}

None of the contributing authors have any conflict of interest, including specific financial interests or relationships and affiliations relevant to the subject matter or materials discussed in the manuscript.

\section{Author details}

'Department of Urology, Mackay Memorial Hospital, No. 92, Sec. 2 ,

Zhongshan N. Rd, Taipei 10449, Taiwan. ${ }^{2}$ School of Medicine, Mackay
Medical College, Sanzhi, Taiwan. ${ }^{3}$ Mackay Junior College of Medicine, Nursing and Management, Taipei, Taiwan.

Received: 27 December 2019 Accepted: 18 March 2020

Published online: 03 April 2020

\section{References}

1. Guan H, Rosenthal DL, Erozan YS. Mullerianosis of the urinary bladder: report of a case with diagnosis suggested in urine cytology and review of literature. Diagn Cytopathol. 2012;40(11):997-1001.

2. Amir RAR, Taheini KM, Sheikh SS. Mullerianosis of the urinary bladder: a case report. Case Rep Oncology. 2018;11(1):206-11.

3. Young $\mathrm{RH}$, Clement PB. Mullerianosis of the urinary bladder. Modern Pathol. 1996:9(7):731-7.

4. Donne C, Vidal M, Buttin X, Becerra P, Carvia R, Zuluaga A, et al. Mullerianosis of the urinary bladder: clinical and immunohistochemical findings. Histopathology. 1998;33(3):290-2.

5. Jimenez-Heffernan JA, Sanchez-Piedra D, Bernaldo de Quiros L, Martinez V. Endosalpingiosis (mullerianosis) of the bladder: a potential source of error in urinary cytology. Cytopathology. 2000;11(5):348-53.

6. Margulis V, Lemack GE, Molberg K, Saboorian MH. Bladder "Mullerianosis" in a woman with lower urinary tract symptoms and hematuria. J Urol. 2001; 165(6 Pt 1):1996-7.

7. Islam S, Tumman JJ, McMahon RF, Payne SR. Mullerianosis of the urinary bladder. BJU Int. 2003;92(Suppl 3):e23.

8. Garavan F, Grainger R, Jeffers M. Endometrioid carcinoma of the urinary bladder complicating vesical Mullerianosis: a case report and review of the literature. Virchows Archiv. 2004;444(6):587-9.

9. Koren J, Mensikova J, Mukensnabl P, Zamecnik M. Mullerianosis of the urinary bladder: report of a case with suggested metaplastic origin. Virchows Archiv. 2006:449(2):268-71.

10. Olivia Vella JE, Nair N, Ferryman SR, Athavale R, Latthe P, Hirschowitz L. Mullerianosis of the urinary bladder. Int J Surg Pathol. 2011;19(4): 548-51.

11. Ogah $\mathrm{K}$, Hartis $\mathrm{R}$, Hilton P. Mullerianosis involving the urinary bladder. Int Urogynecol J. 2012;23(1):123-5.

12. Kudva R, Hegde P. Mullerianosis of the urinary bladder. Indian J Urology. 2012;28(2):206-7.

13. Ndokera R, Brewster S, Dhar S. Mullerianosis: a rare cause of acute renal colic. BMJ Case Rep. 2012;2012:bcr2012006704

14. McSorley S, Kochman A, DeSouza J. Grand rounds: mullerianosis of the urinary bladder in a postmenopausal woman. Urology. 2013;81(3):488-90.

15. Branca G, Barresi V. Mullerianosis of the urinary bladder: a rare tumorlike lesion. Arch Pathol Lab Med. 2014:138(3):432-6.

16. Rajarubendra N, Leang $Y$, Monsour M. Mullerianosis of the urinary bladder ANZ J Surg. 2015:85(4):292-3.

17. Maeda K, Kojima F, Ishida M, Iwai M, Kagotani A, Kawauchi A. Mullerianosis and endosalpingiosis of the urinary bladder: report of two cases with review of the literature. Int J Clin Exp Pathol. 2014;7(7):4408-14. 
18. Stanimir M, ChiuTu LC, Wese S, Milulescu A, Nemes RN, Bratu OG.

Mullerianosis of the urinary bladder: a rare case report and review of the literature. Rom J Morphol Embryol. 2016;57(2 Suppl):849-52.

19. Patel A, Desai P, Malczewski F, Stephens D. Mullerianosis of the urinary bladder: a rare and problematic bladder tumour. BMJ Case Rep. 2017:12:23-8.

\section{Publisher's Note}

Springer Nature remains neutral with regard to jurisdictional claims in published maps and institutional affiliations.

Ready to submit your research? Choose BMC and benefit from:

- fast, convenient online submission

- thorough peer review by experienced researchers in your field

- rapid publication on acceptance

- support for research data, including large and complex data types

- gold Open Access which fosters wider collaboration and increased citations

- maximum visibility for your research: over $100 \mathrm{M}$ website views per year

At $B M C$, research is always in progress.

Learn more biomedcentral.com/submissions 